\title{
The Nixon Busing Bills and Congressional Power*
}

In the eighteen years since the Supreme Court began to desegregate the public schools, no aspect of that painful and complex process has troubled the Court and the country more than the crucial question Brown v. Board of Education ${ }^{1}$ posed but failed to resolve: to what lengths must a once segregated school district go to satisfy the requirements of the Equal Protection Clause? In 1971, the Court reached at least a new interim answer in Swann v. Charlotte-Mecklenburg: desegregation plans must achieve the "greatest possible degree of actual desegregation."2 To reach that goal, a district court may-and in Charlotte-Mecklenburg had no alternative but to-order students transported to schools far from their homes, although not so far "as to either risk the health of the children or significantly impinge on. the educational process."3

In reaching its answer, the Court looked principally to its own prior decisions and to the experience of lower federal courts in grappling with the "flinty, intractable realities" four Presidents and nine Congresses since Brown had largely left this task to the Court. ${ }^{5}$ But within a year of Swann, the President and Congress became leading participants when President Nixon sent to the House of Representatives two proposals, the Equal Educational

* The author wishes to thank Professor Alexander M. Bickel for his assistance in the preparation of this Note.

1. 347 U.S. 483 (1954).

2. 402 U.S. $1,26(1971)$.

3. Id. at $30-31$.

4. Id. at 6 .

5. Title IV of the Civil Rights Act of 1964, 42 U.S.C. $\$ 2000 c-6$ (1970), indicated some carly congressional displeasure with the prospect of busing to achieve desegregation:

Nothing herein shall empower any official or court of the United States to issue any order seeking to achieve a racial balance in any school by requiring the transporta. tion of pupils or students from one school to another or one school district to another in order to achieve such racial balance, or otherwise enlarge the existing power of the court to insure compliance with constitutional standards.

In Swann, the Court read this provision of Title IV as a congressional attempt to insure that the Civil Rights Act did not precipitate an onslaught on de facto scgregation, not as an attempt to restrict the Court in remedying de jure segregation. $402 \mathrm{U}$ S. at 16.18. The Court's interpretation of the provision suggests, at the very least, that it is cx. tremely reluctant to interpret any legislation as a restriction on the federal courts' power to enter busing orders. 
Opportunities $\mathrm{Act}^{\mathfrak{b}}$ and the Student Transportation Moratorium Act, designed to "place firm and effective curbs on busing."s Should the President's bills, or legislation like them, become law, the Court would face for the first time a forceful and direct challenge to its direction and authority in the school desegregation area.

Much of the Equal Educational Opportunities Bill would not trouble a court trying to apply both the bill and Suann's doctrine. In an effort to achieve equal educational opportunity without sacrificing the neighborhood school, the bill directs federal officials to concentrate school aid on schools in low-income areas, ${ }^{9}$ and it permits both the Attorney General and private citizens to sue to remedy denials of equal protection in the schools, which are defined in much the same way the federal courts have. ${ }^{10}$ Most of the bill's restrictions on federal courts can be reconciled with Swann, because they do not prevent a court from resorting to a particular remedy. Busing ranks last on the bill's priority schedule of remedies, ${ }^{11}$ but Swann never

6. H.R. 13915, 92d Cong, 2d Sess. (1972) [hereinafter cited as Equal Educational Opportunities Bill]. Sponsored by Representatives $\mathrm{A}$ cCulloch, Quic and Ford, the bill vias passed in revised form by the House of Representatives August 18, 1972, and sent to the Senate, where it bypassed committee and went directly on to the Senate Calendar. N.Y. Times, Aug. 19, 1972, at 9, col. 1. When the third attempt to cnd a filibuster against the bill failed, the Senate voted on October 12, 1972 to drop the bill for this year. N.X. Times, Oct. 13, 1972, at 1, col. 8.

7. H.R. 13916, 92d Cong., 2d Sess. (1972) [hereinafter cited as Moratorium Bill]. Sponsored by Representatives McCulloch and Ford, the bill has yet to be acted upon. On June 23, 1972, President Nixon signed the Education Amendments of 1972, 1.L. 92-318, 86 Stat. 235, which in $\$ 803$ delayed implementing federal court orders requiring transportation "for the purposes of achieving a balance among the students with respect to race" until all appeals in the case have been exhausted or until January 1, 1974. Reluctantly accepted by both the House and the President, this version of the section nonetheless seems to have greatly lessened the Moratorium Bill's chance for passage. Since this amendment became law, Justice Powell, sitting in his capacity as Circuit Justice for the Fifth Circuit, has refused to stay implementation of an Augusta, Georgia busing order, and Justice Rehnquist has denied similar stays to Nashville and Oklahoma City. N.Y. Times, Sept. 5, 1972, at 23, col. 1. Recently, Justice Douglas denied a motion for a stay involving the Las Vegas school system. N.Y. Times, Sept. 13, 1972, at 35, col. 1.

8. Message From the President of the United States Relative to Busing and Equality of Educational Opportunity, and Transmitting a Draft of Proposed Legislation to Impose a Moratorium on New and Additional Student Transportation, H.R. Doc. No. 92.195, 92d Cong., 2d Sess. (1972) [hereinafter cited as Message], 15.

9. Equal Educational Opportunities Bill, $\$ 101(\mathrm{a})$.

10. Equal Educational Opportunities Bill, $\$ 201$. $\$ \$ 202$ and 203 of the Bill provide, however, that absent a purpose to segregate neither the failure to attain a racial balance nor assignment of pupils to neighborhood schools shall be considered a denial of equal educational opportunity. $\S 301$ grants the right to sue to any individual "denied an equal educational opportunity" and to the Attorney General. \$ 302 gives jurisdiction over such suits to the "appropriate district court of the United States." $\$ 303$ provides for intervention by the Attorney General in private-party suits.

11. $\$ 402$ of the Equal Educational Opportunities Bill provides:

Sec. 402. In formulating a remedy for a denial of cqual educational opportunity or a denial of the equal protection of the laws, which may involve directly or indirectly the transportation of students, a court, department or agency of the United States shall consider and male specific findings on the efficacy in correcting such denial of the following remedies and shall require implementation of the first of 
suggested that busing was a favored remedy. And the district court in Swann had made precisely the finding that must precede increased busing in the upper grades under the bill: that no other method will provide an adequate remedy. ${ }^{12}$

The bill's central provision, however, cuts against Swann. It prevents any federal court or federal agency from implementing a desegregation plan for elementary students (students in the sixth and lower grades) that would increase "either the average daily distance to be traveled by, or the average daily time of travel" for the students or "the average daily number of students . . . transported by an educational agency over the comparable averages for the preceding school year." ${ }^{13}$ In some cases, the Swann standard may be met without re-

the remedies set out below, or in the first combination thercof, which would remedy such denial:

(a) assigning students to the schools closest to their places of residence which provide the appropriate grade level and type of education for such students, taking into account school capacities and natural physical barriers;

(b) assigning students to the schools closest to their place of residence which provide the appropriate grade level and type of education for such students, taking into account only school capacities;

(c) permitting students to transfer from a school in which a majority of the students are of their race, color, or national origin to a school in which a minority of the students are of their race, color, or national origin;

(d) the creation or revision of attendance zones or grade structures without exceeding the transportation limits set forth in section 403 ;

(e) the construction of new schools or the closing of inferior schools;

(f) the construction or establishment of magnet schools or educational parks; or

(g) the development and implementation of any other plan which is educationally sound and administratively feasible, subject to the provisions of sections 403 and 404 of this Act.

12. Swann v. Charlotte-Mecklenburg, 402 U.S. 1, 30 (1971).

13. \& 403 of the Equal Educational Opportunities Bill, crucial to this discussion, provides in full:

\section{TRANSPORTATION OF STUDENTS}

Sec. 403. (a) No court, department, or agency of the United States shall, purstant to section 402 , order the implementation of a plan that would require an increstse for any school year in-

(1) either the average daily distance to be traveled by, or the average daily time of travel for, all students in the sixth grade or below transported by an educational agency over the comparable averages for the preceding school year; or

(2) the average daily number of students in the sixth grade or below transported by an educational agency over the comparable average for the preceding school year, disregarding the transportation of any student which results from a change in such student's residence, his advancement to a higher level of edu. cation, or his attendance at a school operated by an educational agency for the first time.

(b) No court, department, or agency of the United States shall, pursuant to section 402, order the implementation of a plan which would require an increase for any school year in-

(I) either the average daily distance to be traveled by, or the average dally time of travel for, all students in the seventh grade or above transported by an educational agency over the comparable averages for the preceding school year; or

(2) the average daily number of students in the seventh grade or above trans. . ported by an educational agency over the comparable average for the preceding school year, disregarding the transportation of any student which results from 
quiring increased busing, but in the circumstances of Swann, and presumably in other cases, no other method would have achieved a degree of desegregation sufficient to satisfy the Equal Protection Clause. In the district court's plan, busing was a constitutionally necessary remedy. Yet the Supreme Court would have violated the Equal Educational Opportunities Bill ${ }^{1 *}$ in approving it.

The Student Transportation Moratorium Bill has a much less enduring purpose, and its provisions are much simpler. ${ }^{15}$ The bill would give Congress, and the school districts under court order, a breathing spell while more comprehensive legislation is being considered. ${ }^{16}$ It stays all federal court orders that require new busing of any student, or that require any student to be bused to a school other than the one he is currently attending, until July 1,1973 , or until the Congress enacts the kind of plan embodied in the Equal Educational Opportunities Bill. ${ }^{17}$ Had the moratorium been in force

a change in such student's residence, his advancement to a higher level of education, or his attendance at a school operated by an educational agency for the first time,

unless it is demonstrated by clear and convincing evidence that no other method set out in section 402 will provide an adequate remedy for the denial of equal educational opportunity or equal protection of the laws that has been found by such court, department, or agency. The implementation of a plan calling for increased transportation, as described in clause (1) or (2) of this subsection, shall be deemed a temporary measure. In any event such plan shall be subject to the limitation of section 407 of this Act and shall only be ordered in conjunction with the development of a long term plan involving one or more of the remedies set out in clauses (a) through (g) of section 402. If a United States district court orders implementation of a plan requiring an increase in transportation, as described in clause (1) or (2) of this subsection, the appropriate court of appeals shall, upon timely application by a defendant educational agency, grant a stay of such order until it has reviewed such order.

(c) No court, department, or agency of the United States shall require directly or indirectly the transportation of any student if such transportation poses a risk to the health of such student or constitutes a significant impingement on the cdu. cational process with respect to such student.

As passed by the House, the bill prevents a court from entering an order requiring an elementary student to attend any school but the one closest or next closest to his home. N.Y. Times, Aug. 19, 1972, at 9, col. 1 .

14. The plan at issue in Swann required the Charlotte-Arecklenburg school district to purchase 198 more buses. 402 U.S. at $30, \mathrm{n} .12$. If more buses mean more students being bused, the Court's plan would have run afoul of the Equal Educational Oppor. tunities Bill's $\$ 403(\mathrm{a})(2)$.

15. Because this bill's provisions depend for their constitutionality on the same issue its companion bill raises-congressional power to restrict the scope of remedies open to federal courts in entering desegregation decrees-it will not be discussed sepa. rately. If Congress has the power permanently to stop courts from entering certain busing orders, surely it has the power to do so temporarily. Sce Professor Robert Bork's more detailed treatment of this point in his defense of the busing bills, Bork, Constitutionality of the President's Busing Proposals (American Enterprise Institute, 1972), 17-19, see also Home Building \& Loan Ass'n v. Blaisdell, 290 US. 398 (1934); Bickcl, What's Wrong with Nixon's Busing Bills?, New RepubLic, Apr. 22, 1972, at 19, 20.

16. Moratorium Bill, § 2(b).

17. $\$ 3(a)$ of the Moratorium Bill stays any federal order "to the extent it requires, directly or indirectly, a local educational agency

(l) to transport a student who was not being transported by such local educational 
when Swann was decided, it would have completely prevented the implementation of the district court's plan, although it would have done so for only a short time.

Should another case like Swann-a hypothetical "Swann II"-arise with these bills in force, the Court would be compelled to accept or reject their assertion of congressional authority in an area that until now has been occupied exclusively and powerfully by the judiciary. In his message to Congress, the President suggested that Congress has power under the enforcement clause of the Fourteenth Amendment to enact his bills. ${ }^{\text {is }}$ Other proponents of the Administration plan have argued that Article III, with its grant to Congress of power over federal jurisdiction, settles whatever constitutional problems the busing bills create. ${ }^{19}$ Either of these claims to congressional power, heard in full and accepted by a court reconsidering Swann, not only would profoundly alter the present prospects for school desegregation but might also redefine the basic and enduring outlines of the Supreme Court's role in shaping the law.

\section{Article III: Jurisdiction and Remedies}

Any court reconsidering Stwann would face the Article III argument as a threshold question: does the congressional power over jurisdiction encompass the strict prohibitions of the busing bills? The bills, of course, are not now phrased in jurisdictional terms, and the court might avoid any inquiry relating to Article III by noting that Congress did not make explicit its reliance on its power over jurisdiction. Recasting them to refer explicitly to Article III would require some skill in drafting, lest they open unforeseen jurisdictional gaps, and the bills would read much more awkwardly as a result. ${ }^{20}$ But no real distinction can be drawn between a bill that begins "No court shall enter an order that ..." and one that reads "No court shall have jurisdiction to enter an order that ...." A court searching for constitutional support for the Nixon busing plan should look to substance, not form, and therefore should turn first to Article III.

agency immediately prior to the entry of such order; or

(2) to transport a student to or from a school to which or from which such student was not being transported by such local educational agency immediately prior to the entry of such order."

18. Message 2.

19. Acting Attorney General Kleindeinst took this position the day after the president outlined his busing proposals on national television. N.Y. Times, Mar. 18, 1972, at 1, col. 8. Columnist William F. Buckley, Jr. came to the same conclusion in a column entitled "Curb the Courts?" New Haven Journal-Courier, May 4, 1972, at 11, col. 1.

20. For a discussion of such possible redrafting, see Bork, supra note 15, at 6 . 
Section 1 of Article III vests the "judicial Power of the United States" in "one supreme Court and in such inferior Courts as the Congress may from time to time ordain and establish." 21 Section 2 of Article III grants the Supreme Court appellate jurisdiction over certain classes of cases, "with such Exceptions, and under such Regulations as the Congress shall make." federal courts and confers jurisdiction on them, surely it can remove jurisdiction. The busing bills-so the argument runs-amount to an exercise of congressional power over federal jurisdiction, depriving courts of the power to enter certain kinds of busing orders. But in cases arising under both Section 1 and Section 2 of Article III, the Supreme Court has indicated that Congress may not, in the guise of exercising power over jurisdiction, enact legislation it could not enact under some other grant of power. The power over jurisdiction is just that: a power to grant or withhold jurisdiction, not a disguised power to revise the Court's reading of the Constitution.

\section{A. Section 1: Power Over Inferior Courts}

A court reconsidering Swann in light of the Busing Acts would turn to the Norris-LaGuardia $\mathrm{Act}^{23}$ and the Emergency Price Control Act of $1942^{24}$ as the modern statutory precedents in which Congress read its Article III mandate most broadly. In neither instance, however, did Congress assert a power to regulate the jurisdiction of lower courts as sweepingly as it would by enacting the busing bills.

Proponents of the 1932 Norris-LaGuardia Act, including the House and Senate Committees, advanced the same kind of claims to Article III power as those a court would face in trying to apply the Busing Acts to a second Swann case. ${ }^{25}$ The Act's authors phrased it in jurisdictional terms in an attempt to skirt constitutional problems by explicitly invoking Article III. Titled "AN ACT to amend the Judicial Code and to define and limit the jurisdiction of courts sitting in equity, and for other purposes," it removed the jurisdiction of

21. Article I, Section 8 grants Congress the concomitant power to "constitute tribunals inferior to the Supreme Court."

22. The Supreme Court has read these clauses to give Congress a very broad power indeed: "Courts created by statute have no jurisdiction but such as the statute confers." Sheldon v. Sill, 49 U.S. (8 How.) 441, 449 (1850). See also Kline v. Burke Construction Co., 260 U.S. 226 (1922); Mayor v. Cooper, 73 U.S. (6 Wall.) 247 (1867); Cary v. Curtis, 44 U.S. (3 How.) 236 (1845).

23. 29 U.S.C. $\$ \S 101-15$ (1970).

24. Act of January 30,1942 , ch. 26,56 Stat. 23.

25. See, e.g., H.R. REp. No. 669, 72d Cong., Ist Sess. (1932), S. Rer. Nio. I63, 72d Cong., Ist Sess. (1932). 
federal courts to issue an injunction in labor disputes except in extreme circumstances. ${ }^{26}$ Felix Frankfurter, then professor of law at Harvard and a principal draftsman of the bill, examined the Article III cases in a brief appendix to the House Report and concluded that the principal limit on congressional power grew out of the separation of powers doctrine. ${ }^{2 \pi}$ "For Congress itself to hesitate" to pass the Act on constitutional grounds, he wrote, "would seem to be a paradoxical act of self-abnegation." 28

Six years after the Norris-LaGuardia Act became law, the Supreme Court in Lauf v. E.G. Shinner \& Co. disposed of the constitutional objections to the Act in one sentence: "There can be no question," the Court said, "of the power of Congress thus to define and limit the jurisdiction of the inferior courts of the United States."

Truax v. Corrigan ${ }^{30}$ decided nine years before the Norris-LaGuardia Act was passed, seemed to give the labor injunction the status of a constitutional right. If the Congress in passing the Act and the Court in considering it read Truax this way, the Act would be even more forceful precedent for the busing bills. The Court in Truax found that a state statute prohibiting injunctions for certain acts in a labor dispute violated both the Equal Protection and the Due Process Clauses of the Fourteenth Amendment. Since both Truax and Lauf dealt with statutory limitations on a court's injunctive powers, together they might be read to say that Congress, because it has Article III powers, may violate the Due Process Clause-while the states, which lack such a power over federal jurisdiction, may not.

But the Truax majority did not announce a constitutional right to a labor injunction. The Court thought that the state statute granted "complete immunity from any civil or criminal action to the defendants,"31 thus preventing an employer from obtaining any remedy. The Court in Truax read the state statute as removing all remedics, not just injunctions; the Norris-LaGuardia Act affected only injunctions and so arguably did not run afoul of the Truax doctrine. And it could be, of course, that the Court in Lauf simply changed its mind

26. 29 U.S.C. $\S \S 101,104,107$.

27. Frankfurter, Power of Congress Over Equity Jurisdiction of the Federal Courls, H.R. REP. No. 669, supra note 25, at 12-16.

28. Id. at 16 .

29. 303 U.S. 323,330 (1938).

30. 257 U.S. 312 (1921).

31. Id. at 328. Frankfurter, too, argued for this reading of the case: "Certainly the Truax case did not maintain that withdrawal of injunctive relief alone denied duc process of law." Frankfurter \& Greene, Congressional Power over the Labor Injunction, 31 Colum. L. Rev. 385, 408 (1931). 
when pressed by Congress. If an employer had been granted a "constitutional right" to a labor injunction under Truax, it may have been abandoned by the Court, like other ill-fated doctrines, with the wane of substantive due process. Lauf provides no clue as to which interpretation of the Norris-LaGuardia Act the Court favored.

Nor did the Norris-LaGuardia Act go quite so far as the busing bills in its attempts to end the excesses of federal courts. As Professor Frankfurter himself acknowledged, the Norris-LaGuardia Act accorded only limited immunity: "it is not immunity from legal as distinguished from equitable remedies-hitherto unlawful conduct remains unlawful; ...." 32 He noted too that the Act limited only the power to enjoin: "all other remedies in federal courts and all remedies in state courts remain open." 33 The Norris-LaGuardia Act reflected a congressional choice of remedy, foreclosing one remedy in some circumstances, but leaving others open in all circumstances. The Act provides no support for the busing bills unless they, like it, foreclose only one of several remedies.

Moreover, federal courts issued injunctions in labor disputes to remedy violations of the common law or a particular statute, such as the Sherman Act with its prohibition on "restraints of trade." 34 None of these wrongs were direct violations of the Constitution, and to the extent that the union's crimes originated in statutes or the common law, Congress could redefine them. In the cases the Norris-LaGuardia Act addressed, Congress and not the Constitution controlled the rights whose violation triggered the federal jurisdiction. But in desegregation cases the Constitution does bring federal equity power into play. Insofar as the Constitution requires the courts to remedy state denials of equal protection, congressional curbs on the scope of remedies available to the courts must rest on different constitutional ground than did the Norris-LaGuardia Act. A court deciding Swann II must therefore look to different precedent.

Ten years after passing the Norris-LaGuardia Act, Congress again invoked Article III in adopting the Emergency Price Control Act. ${ }^{35}$ In its attempt to facilitate wartime price control, Congress raised con-

32. F. Frankfurter \& N. Greene, The Lador Injunction 215 (1980).

33. Id. at 220. Justice Frankfurter took precisely the opposite position writing for the majority in United States v. Hutcheson, 312 US. 219 (1911), without acknowledging the Professor's earlier views.

34. See F. Frankfurter \& N. Greene, The Labor INJuxction, supra note 31, at 5-17.

35. Act of January 30, 1942, ch. 26, 56 Stat. 23. For a complete outline of the Act's provisions, see H.R. Rer. No. 1409, 77 th Cong., Ist Sess. (1941); sec also Reid \& Hatton, Price Control and National Defense, 36 IRL. L. REv. 255 (1942); Note, Administratin'e Features of the Emergency Price Control Act, 28 VA. L. REv. 991 (1949). 
stitutional issues much like those raised by the busing bills, and certainly as serious. The Act's jurisdictional provisions, similar in many respects to the more modest 1971 price control legislation, ${ }^{\text {at }}$ removed the jurisdiction of federal district and state courts to consider the validity, under the Act or the Constitution, of the regulations promulgated by the Price Administrator, and it stripped them of power to enjoin the enforcement of any set of regulations. ${ }^{37}$ Instend, the Act granted an Emergency Court of Appeals and (on appeal from its judgments) the Supreme Court exclusive jurisdiction to set aside price regulations. ${ }^{38}$ The Act also limited the time for contesting a regulation's validity. ${ }^{30}$ The Emergency Court could set aside a regulation only on final judgment; it could not issue a temporary restraining order or interlocutory decree..$^{40}$ And the Act postponed the effect of even a final decree of invalidity pending expeditious review in the Supreme Court. ${ }^{41}$

The Act's proponents thought that Article III gave Congress power thus to regulate the jurisdiction of inferior federal courts, ${ }^{42}$ and in Lockerty v. Phillips, ${ }^{43}$ decided in 1943, the Supreme Court agreed with part of their theory. The Court used broad language in holding that a district court could not set aside, even on constitutional grounds, a regulation. The Constitution "left Congress free to establish in-

36. The Economic Stabilization Act Amendments of 1971 duplicate the 19.12 Act's provisions in some respects in $\$ 211$. Pub. L. No. 92-210 (December 22, 1971). The $\Lambda \mathrm{ct}$ vests exclusive jurisdiction over price control appeals in a Temporary Emergency Court of Appeals just as the Emergency Price Control Act did. Id. at \$21I(b). The Emergency Court has exclusive jurisdiction to determine the constitutional validity of any regula. tion or order (id. at $\$ 211(\mathrm{~g})$; constitutional defenses may be raised in a district court enforcement proceeding, but they are to be certified to the Emergency Court. Id. at $\$ 211(\mathrm{c})$. A district court thus may set regulations aside as invalid under the statute, but it may not set any regulation aside as invalid under the Constitution. Id, at \$\$ 211(d), (e). Regulations may be set aside only on final judgment, and an appeal atito. matically stays the effect of a final judgment of invalidity. Id. at $\$ \S 211(\mathrm{c})$, (f).

37. Act of January 30,1942 , ch. $26, \S 204(\mathrm{~d}), 56$ Stat. 23.

38. Id.

39. Id. at $\$ \S 203(a), 204$ (a). An aggrieved individual had to filc objections to a regulation with the Administrator within sixty days of its issuance; after the $\Lambda$ dministrator's decision, an appeal could be taken to the Emergency Court of $A$ ppeals within thirty days.

40. Id. at $\$ 204(c)$.

41. Id. at $\$ 204(\mathrm{~b})$.

42. The Administrator of the OPA argued in the House hearings that "there cat1 be no question of the constitutional power of Congress to vest in the cincrgency coltrt cxclusive jurisdiction to determine the validity of ceiling regulations and orders"; he cited Lauf for the proposition that "Congress may define, limit, or entircly withdraw the power of the federal courts to issue injunctions in particular classes of cases." He'ar. ings on H.R. 5479 (superseded by H.R. 5990) Before the House Comm. on Danling and Currency, F7th Cong., lst Sess. 336 (1941). See also id. at 63.87; Nathanson, The Emer. gency Price Control Act of 19f2: Administrative Procedure and Judicial Review, 9 LAw \& Contemp. Prob. 60 (1942); Comment, Judicial Review of Price Orders tuider thu Emergency Price Control Act, 37 ILL. L. REv. 256 (1942).

43. 319 U.S. 182 (1943). 
ferior federal courts or not as it thought appropriate," and Congress could remove certain kinds of cases from their jurisdiction. ${ }^{\text {At }}$ The Court noted carefully, however, that the Act did permit constitutional challenge in the Emergency Court since "a construction of the statute which would deny all opportunity for judicial determination of an asserted constitutional right is not to be favored."ts Lockerly may be read to say merely that the Price Control Act, like the Norris-LaGuardia Act, removed one remedy while substituting another.

In Lockerty, where plaintiffs had simply challenged a set of regulations, the constitutional debate was limited and slightly abstract. But in Yakus v. United States, ${ }^{40}$ decided the same year, the Court faced a stark due process issue. An enforcement court, in convicting Yakus, refused even to question the constitutionality of the regulations involved, and it denied him a stay of enforcement pending appeal. In affirming the convictions, the Supreme Court clarified the scope and limits of Article III power.

Answering defendants' contention that prohibiting issuance of stay orders during a challenge in the Emergency Court denied them due process of law, the Court noted that "the award of an interlocutory injunction by courts of equity has never been regarded as strictly a matter of right." $4 \pi$ When public, as opposed to purely private, interests will be affected by a stay order, the Court argued, a district judge must himself balance the potential damage to the public interest against the potential damage to a private party. Here Congress had done the balancing in price control cases and the Court would abide by its conclusion. ${ }^{48}$ Advocates of the busing bill would argue that a court must for the same reason abide by the congressional judgment about busing orders.

Petitioners in Yakus argued also that the Act denied them due process of law by removing the enforcement court's jurisdiction to examine the validity of the very regulations it had enforced. But the Court refused to look at a district court enforcement proceeding

\footnotetext{
44. Id. at 187 .

45. Id. at 188 .

46. 321 U.S. 414 (1914).

47. Id. at 440 .

48. Id. at 441-42. OPA Administrator Henderson made the same argument in the House hearings: "These provisions merely crystallize the wcll-cstablished equitable doctrine that equity courts will not issue preliminary injunctions where the public interest would suffer irreparable injury." Hearings, supra note 42, at 310. The Court had used this kind of reasoning in upholding congressional power under Article III to prevent federal courts from enjoining state proceedings in certain cases. Great Lakes Dredge \& Dock Co. v. Huffman, 319 US. 293 (1943); Kline v. Burke Construction Co., 260 Ư.S. 226 (1922).
} 
apart from the overall statutory scheme. The statute gave those subject to it one opportunity to litigate all issues, including the validity of newly issued regulations, and the Constitution required no more. The statutory scheme for allocating issues among different courts must provide an accused with "an adequate opportunity to be heard on the question of validity," 40 but petitioners in Yakus made no showing that they had lacked such an opportunity.

For a court reconsidering Swann in light of the busing bills, the price control cases seem to be forceful precedent; they suggest that Congress may remove a district court's power even to hear a defendant's claim that he has been denied due process of law. But the Emergency Price Control Act granted to another federal court the same jurisdiction it removed from district courts. Unless it is only a perfunctory provision, Article III must empower Congress to allocatte "cases and controversies" among courts of discrete jurisdiction in this fashion. The busing bills do not transfer jurisdiction, they divest federal courts of the power to enter certain busing orders; the Price Control Act is thus a poor analogy to them. Congress may take away a federal court's power to hear constitutional claims-but only if it gives the same power to other federal courts. Article III, the Yakus Court thought, would not support the Emergency Price Control Act "if by statutory command or in operation it will deny, to those charged with violations, an adequate opportunity to be heard on the question of validity." "so

Dealing with these cases in his landmark discussion of congressional power over inferior courts, ${ }^{51}$ Professor Hart rejected an argument that would bring the busing bills within Article III. Congressional power over jurisdictions is subject "in whole not in part" to "the other provisions of the Constitution," and it does not amount to an unlimited power to affect constitutional rights:

49. 321 U.S. at 446 .

50. 321 U.S. at 446. In Crowell v. Benson, 285 U.S. 22 (1932), the Court reached a result consistent with this analysis in considering the Longshoremen's and Harbor Workers' Compensation Act (Act of March 4, 1927, ch. 509, 44 Stat. 1424). Nlthough Congress may preclude district courts from conducting a de novo hearing into facts established by an administrative tribunal, it may not preclude full enquiry into those facts that establish the tribunal's jurisdiction; "the essential independence of thu exercise of the judicial power of the United States in the enforcement of constitutionat rights requires that the Federal court should determine such an isste upon its own record and the facts elicited before it." 285 U.S. at 64 . The "jurisdictional facts" doctrine is now in some disrepute (see 5 Moore's Federal Prictice $\$ 38.08$ [2], at 52 (2d ed. 1971)), but even Brandeis in dissent agreed with the proposition that in "certain circumstances, the constitutional requirement of due process is a requirement of judicial process," 285 U.S. at 87 .

51. Hart, The Power of Congress to Limit the Jurisdiction of Federal Courts: An Exercise In Dialectic, 66 HARv. L. REv. 1362 (1953). 
Why, what monstrous illogic! To build up a mere power to regulate jurisdiction into a power to affect rights having nothing to do with jurisdiction! And into a power to do it in contradiction to all the other terms of the very document which confers the power to regulate jurisdiction! ${ }^{52}$

Both the Norris-LaGuardia Act and the Emergency Price Control Act, although they assert as strongly as any modern legislation a claim to broad power under Article III, remain consistent with Professor Hart's analysis. The busing bills do more:

1. They remove the jurisdiction of all federal courts to enter certain kinds of desegregation decrees; Yakus and Lockerly found in Article III only the porver to allocate jurisdiction, not to remove it.

2. They restrict federal courts in remedying constitutional wrongs; the Norris-LaGuardia Act limited equity power in cases of statutory or common law origin.

3. They remove, at least in part, one remedy for a state's denial of equal protection; to the extent that this remedy is the only remedy, the Norris-LaGuardia Act is poor precedent for them.

As an exercise in regulating jurisdiction, the busing bills can find little constitutional support in even the strongest congressional claims to Article III porver over inferior federal courts. The bills attempt to alter substantially not just the manner but the extent to which constitutional rights may be vindicated, and Section 1 of Article III gives Congress no such power.

\section{B. Section 2: Power Over the Supreme Court}

Section 1 of Article III gives Congress power over only inferior federal courts; to limit the jurisdiction of the Supreme Court, the busing bills must turn to Section 2. The bills do not by their terms address the state courts, and presumably these courts would be free to enter busing orders without regard to the restrictions on federal courts. ${ }^{53}$

52. Id. at 1371. Not only is the congressional power over jurisdiction subject "in whole not in part" to "the other provisions of the Constitution," but it is only a power over jurisdiction, a power to determine what courts shall hear and decide a class of cases rather than a power to influence the nature of the decision in a manner inconsistent with the Constitution. Although Hart argues that "it's hard, for me at least, to read into Article III any guarantee to a civil litigant of a hearing in a federal constitutional court ...." nonetheless if "Congress directs an Article III court to dccide a case, I can easily read into Article III $\mathbf{a}$ limitation on the poricr of Congress to tell the Court how to decide it." Id. at 1372-73. And, Hart argues, Congress may not even be able to withdraw a class of cases from the federal jurisdiction where the constitutional scheme requires that federal courts decide that kind of case, as in federal habeas corpus cases. Cf. note 68 infra. Certainly, he argues, Congress cannot direet the Court to ignore the due process clause in considering a petition. Id. at 1393.

53. Both bills leave state courts and state agencies free to ignore the restrictions on busing. Moratorium Bill $\$ 3(c)$; Equal Educational Opportunities Bill $\$ 405$. 
Certainly state courts must enforce the Fourteenth Amendment no less zealously than federal courts; though they have not been the chief instruments of desegregation, the state courts have played a role too. ${ }^{54}$ The busing bills would, however, limit the role of the Supreme Court on appeal from such state judgments under all but the most disingenuous reading of the bills' provisions.55 If Article III provides constitutional support for the bills as they affect the Supreme Court, it is because the bills are "exceptions" to or "regulations" of the Court's appellate jurisdiction.

Article III power over the jurisdiction of the Supreme Court reached its high-water mark a century ago in Ex parte McCardle.t" Congress succeeded, or so it seemed, in doing much more than the busing bills try to do: it stripped the Supreme Court of power to decide a class of sensitive cases, including a case in which the Court had already heard argument. A court trying to reconcile Swann II with the Busing Act's limitations on the Supreme Court would turn to McCardle to find the outer limits of congressional power under Section 2 of Article III.

McCardle, a Mississippi newspaper editor arrested and imprisoned awaiting trial by the military command, brought and lost a habeas corpus petition in the Circuit Court for the Southern District of Mississippi. He used an 1867 procedural statute to appeal his conviction to the Supreme Court..$^{57}$ McCardle was a civilian, and Congress feared that the Court would declare the Reconstruction Acts unconstitutional in granting his petition. ${ }^{58}$ So Congress repealed the 1867 appeals act in the midst of argument before the Court..5

The Court held unanimously that Congress had the power under

54. See, e.g., Morton v. City Commissioners of Parsons, 178 Kan. 282, 285 P.2d 774 (1955); Moorman v. Morgan, 285 S.W.2d 146 (Ky. Ct. App. 1955); Vetcre v. Allen, 15 N.Y.2d 259, 258 N.Y.S.2d 77, 206 N.E.2d 174, cert. denied, 382 U.S. 825 (1965); $\Lambda$ ddabbo v. Donovan, 22 A.D.2d 383, 256 N.Y.S.2d 178 (2d Dep't), aff'd, 16 N.Y.2d 619, 261 N.Y.S.2d 68, 209 N.E.2d 112, cert. denied, 382 U.S. 905 (1965). See also Note, Racial Imbalance in the Public Schools: Constitutional Dimensions and Judicial Response, 18 VANv. L. REV. 1290, n.180, 1319-21 (1965).

55. Since both bills prevent only federal courts from entering the proscribed remedies, it might be argued that the Court could, consistent with the bills provision, requirc state courts to enter orders a federal court could not. The Moratorium Bill scems to anticipate this sophistry; the Equal Educational Opportunitics Bill does not.

56. 74 U.S. (7 Wall.) 506 (1868). See Levy, Congressional Power Over the Appellatc Jurisdiction of the Supreme Court: A Reappraisal, 22 N.Y.U. INTRA. L. REv. 178 (1967).

57. Act of February 5, 1867, ch. 28, 14 Stat. 385 .

58. For a discussion of this whole episode, see 2 C. Warren, Tile Supreme Coukr in UNITED STATES History 455-97 (1928). The Court had twice before refused to rule on the Reconstruction Acts. In Mississippi v. Johnson, 71 U.S. (4 Wall.) 475 (1866), the Court dismissed for lack of jurisdiction a suit to enjoin President Johnson from carrying out the Acts; in Georgia v. Stanton, 73 U.S. (6 Wall.) 50 (1867), the Court dismissed a similar suit against the Secretary of War.

59. Act of March 27, 1868, ch. 34, 15 Stat. 44. 
Article III to make exceptions like this one to the appellate jurisdiction of the Supreme Court. The Court faced an express repeal of an authorizing statute, and it could not "imagine a plainer instance of positive exception." 80 The Court announced its inability to proceed and dismissed for lack of jurisdiction without further analysis.

Few cases have aroused the Congress as much as McCardle, and few courts have faced the intense pressure the Chase Court faced in deciding McCardle. With troops in the streets of the capital and the President of the United States on trial before the Senate, a less ideal setting for dispassionate judicial inquiry could hardly be imagined. Moreover, McCardle's holding and reasoning may not retain whatever vitality they once had. ${ }^{61}$ Of course the gravity of the issues involved does not minimize the directness of the decision, and certainly no court has ever overruled McCardle. But even if McCardle stands, it does not support claims to unbounded congressional power under Section 2 of Article III.

A year after McCardle seemed to block all habeas corpus appeals, the Court decided in a virtually identical case that at least one procedure for appeal remained open. ${ }^{62}$ A Mississippi civilian, arrested by military authorities for trial before a military commission, appealed the circuit court decision denying his petition for habeas corpus. He ignored the now defunct 1867 procedure and invoked the Judiciary Act of $1789^{\text {B3 }}$ to ask the Court for an original writ of habeas corpus on the basis of a record brought up by certiorari. In deciding Ex parle Yerger, ${ }^{64}$ an again unanimous Court construed the 1868 repealer to remove only the procedures for appeal created by the 1867 Act. Yerger's route to the Supreme Court was a tortuous one, but it was clear that the Courc retained jurisdiction of habeas corpus appeals.

$M c C a r d l e$ becomes quite a different case when read in light of $Y e r-$ ger, and a less forceful precedent for the court deciding Swann II. The 1868 repealer, which $M c$ Cardle found constitutional, simply removed one of two equally effective means for obtaining Supreme Court review in habeas corpus cases; like the Norris-LaGuardia Act, the repealer expressed a congressional choice among remedies. ${ }^{\text {os }}$ MicCardle's language seems to go further, but in view of Yerger it should be

60. 74 U.S. (7 Wall.) at 514.

61. Dissenting in Glidden v. Zdanok, 370 U.S. 530 (1962), Justice Douglas doubted that McCardle's holding "could command a majority vicw today". Id. at 605 n.ll.

62. Ex parte Yerger, 75 U.S. (8 Wall.) 85 (1868).

63. Act of September 24, 1789, ch. 20, $\$ 14,1$ Stat. 82.

64. 75 U.S. (8 Wall.) 85 (1869).

65. See Ratner, Congressional Power Over the Appellate Jurisdiction of the Supreme Court, 109 U. PA. L. REv. 157, 180 (1960). 
read for "the least it has to be worth" rather than "all it might be worth." $"$ "This reading of the case would explain why the Court took the trouble in McCardle to point out that the repealer did not neces. sarily deny "the whole appellate power of the court, in cases of habeas corpus," and to note that the 1868 Act did not remove from the Court's "jurisdiction any cases but appeals from Circuit Courts under the Act of 1867." 67

To the extent that it actually relied upon the rationale later expressed in Yerger, the McCardle Court never faced a serious constitutional conflict, although clearly it faced the gravest of institutional conflicts. Indeed, Yerger contains suggestions that, had Congress eliminated all review of habeas corpus actions, the result even in McCardle might have been different. ${ }^{68}$ If any implications are to be drawn from these two cases, one of them must be that there are substantive limits to the exercise of congressional power under Section 2 of Article III. In United States $v$. Klein, ${ }^{80}$ decided only three years after Yerger, the Court found that Congress had passed such a limit.

An 1863 statute permitted executor Klein to recover property confiscated during the war upon proof that its owner "has never given any aid or comfort to the present rebellion."70 Klein's decedent had been granted an executive pardon in 1864, and the Court's recent decision that such a pardon erased any rebel taint for a recovery proceeding evidently precipitated Klein's claim. ${ }^{71}$ But Congress had answered the Court by removing its jurisdiction to hear cases where the only proof of innocence was an executive pardon, ${ }^{72}$ and the Court faced this Act for the first time when the Government appealed Klein's victory. The Court, in affirming the Court of Claims, found the Act an unconstitutional attempt to "prescribe rules for decision to the

66. Hart, supra note 50 , at 1364 .

67. 74 U.S. (7 Wall.) at 515.

68. Chief Justice Chase quoted the constitutional prohibition against suspendingt the writ in Article I, Section 9 , noted the provisions of the Judiciary $\Lambda$ ct of 1789 , and then wrote:

It would have been, indeed, a remarkable anomaly if this court, ordaincd by thic Constitution for the exercise, in the United States, of the most important powers in civil cases of all the highest courts of England, had been denied, under a Con. stitution which absolutely prohibits the suspension of the writ, except under ex. traordinary exigencies, that power in cases of alleged unlawful restraints, whicli the Habeas Corpus Act of Charles II expressly declares those courts to possess.

75 U.S. at 96 . For a more explicit and modern version of this argument, sce Eisentrager v. Forrestal, 174 F.2d 961 (D.C. Cir. 1949).

69. 80 U.S. (13 Wall.) 128 (1872).

70. Act of March 3,1863, ch. 120, 12 Stat. 820.

71. United States v. Padelford, 76 U.S. (9 Wall.) 531 (1870).

72. Act of July 12, 1870, ch. 251, 16 Stat. 230, 235. 
Judicial Department"73 and to interfere with the executive's power to pardon.

In Klein, the Court says quite clearly that Article III gives Congress no blank check; a statute denying jurisdiction is not for that reason alone insulated from judicial scrutiny. Moreover, the Court held that some denials of jurisdiction conflict with the scheme of the Constitution. Although it may regulate and make exceptions to the Supreme Court's appellate jurisdiction, the Congress may not remove certain attributes of judicial power-in Klein, the power to construe the effect of an executive pardon-under the guise of removing jurisdiction. Although it does not so hold, Klein does suggest that an appeal to Article III will not save a statute inconsistent with other parts of the Constitution, and it indicates that the Court will protect rights and powers granted by the Constitution from an Article III attack.

Congress has on other occasions exercised or threatened to exercise its power under Section 2 of Article III, but in no instance has it done so as forcefully as it did in McCardle. MIcCardle would lend support to the busing bills' restrictions on the Supreme Court if any case would. Yet, when read with its contemporaries, it does not. The cases dealing with congressional power over the Supreme Court may, in fact, cut the other way; some of the scholars who have examined them argue that Congress may not, in the exercise of its power over the jurisdiction of the Supreme Court, impair any of the Court's "essential constitutional functions." $"$ it

But the court deciding Swann II need not wait for the results of the

73. 80 U.S. (13 Wall.) at 146.

74. Ratner, supra note 65 , argues strongly for the proposition that congressional power over the appellate jurisdiction of the Supreme Court cannot be used to impair its "essential constitutional functions": "constitutional limitations are not transgressed so long as the Court remains available ultimately to resolve conflicts between state and federal law by lower courts." Id. at 201. Herbert Wechsler takes issue with Ratner's standard, arguing "that Congress has the power by enactment of a statute to strike at what it deems judicial excess by delimitations of the jurisdiction of the lower courts and of the Supreme Court's appellate jurisdiction." Wechsler, The Courts and the Constitution, 65 Colum. L. REv. 1001, 1005 (1965). At the same time, though, he recognizes that Article III grants only a power to withdraw jurisdiction and "when I speals of withdrawal I mean, of course, complete climination of all cognizance of eases of the kind. Congress could not, for example, employ federal courts as organs of enforcement and preclude them from attending to the Constitution in arrising at decision of the cause." Id. at 1006. He seems to accept Hart's proposition that "jurisdiction is always jurisdiction only to decide constitutionally." Hart, supra note 50 , at 1102 . See also R. Berger, Coxgress v. The Surreme Court (1969). Berger takes a fresh look at the framers' view of Article III power over the Supreme Court and concludes that their main concern was with standards for appellate review of lower court fact findings. Because the problem of setting standards was so subtle and current practice so complex, "it was concluded to leave the problem for handling by the Congress lirough the medium of the "exceptions' clause." Id. at 289. Berger concludes that history supports Professor Hart's view of the power to make cxceptions to the jurisdiction of the Supreme Court. 
scholarly debate; the busing bills do more than even McCardle permits under Section 2 of Article III:

1. They remove completely the Court's jurisdiction to require lower or state courts to enter certain kinds of desegregation orders; in McCardle, Congress had removed only one method of seeking Supreme Court review.

2. They shift the burden of deciding how to enforce the Fourteenth Amendment in the schools from the Court to Congress. To the extent that this shift cuts across a scheme implicit in the Fourteenth Amendment, Klein suggests that the busing bills cannot find support in Article III.

A court reconsidering Swann, then, cannot end its inquiry with a nod to congressional power over jurisdiction. If Article III gives the federal courts the power conclusively to interpret the Constitution, it cannot at the same time give Congress the power to override the courts by invoking the magic term "jurisdiction." Marbury \%. Madison rejected such a reading of the Article. Congressional power over jurisdiction is subject "in whole not in part" to "other provisions of the Constitution," ${ }^{75}$ and the busing bills find constitutional support in Article III only to the extent that they do not run afoul of the Constitution's substantive guarantees. ${ }^{70}$

\section{The Fourteenth Amendment: Rights and Remedies}

The Supreme Court has found the mandate for every school desegregation decision from Brown v. Board of Education ${ }^{77}$ through Swann in the Equal Protection Clause of the Fourteenth Amendment. The Court, in deciding a second Swann, would look to it again. In Section 1, the Amendment provides: "No state shall . . . deny to any person within its jurisdiction the equal protection of the laws." Though the federal courts have taken the lead in enforcing the Equal Protection Clause in the schools, Section 5 of the Amendment expressly grants enforcement power to Congress: "Congress shall have power to enforce, by appropriate legislation, the provisions of this article."78

75. Hart, supra note 51, at 1372.

76. Because he insists that busing is always just one remedy among many, Professor Bork suggests that Article III may give Congress power to enact the busing bills. But because he sees "no point in precipitating a possible constitutional crisis unnecessarlly," he suggests that Congress look elsewhere. Bork, supra note 15, at 8.

77. 347 U.S. 483 (1954).

78. If the restrictions on federal court busing orders like those in the busing bllls were enacted as a separate measure, as a restriction on federal courts and not as part 
The "original understanding" of the meaning of the Fourteenth Amendment, if indeed its authors and their contemporaries shared one, has been obscured by a century of interpretation and gloss. ${ }^{70}$ Two years after its 1868 ratification, the Supreme Court construed the Equal Protection Clause narrowly. ${ }^{80} \mathrm{~A}$ decade later, in the Civil Rights Cases, ${ }^{81}$ the Court held that congressional power under Section 5 of the Amendment extended only to developing remedies for state action that, in the exclusive judgment of the Court, denied equal protection or due process. The Court's original view of congressional power under Section 5 outlived the restrictive application of Section 1 announced in the Slaughterhouse Cases, 82 and survived into the era in which the Equal Protection Clause received its most expansive reading. Congress, too, stayed within the boundaries set by the Court; the landmark Civil Rights Act of 1964, for example, depended for its constitutionality not upon the Fourteenth Amendment but upon the commerce porwer. ${ }^{83}$ But the Court abandoned this re-

of an attack on segregation, they could draw constitutional support from the Fourteenth Amendment only to the extent that busing itself constitutes a denial of equal protection. Only the denial of equal protection-found or foreseen by Congress or the Court-activates the enforcement clause of Section 5. See, e.g., Katzenbach v. Morgan, 384 U.S. 64I (1966). After Swann and its companion case MfCDanicl v. Barresi, 402 U.S. 39 (1971), the Court could see no busing order in this light. In MeDaniel, the Supreme Court of Georgia had directed a lower court to enjoin the enforcement of a local board's desegregation plan because it violated the Fourteenth Amendment "by" treating students differently because of their race." Barresi v. Browne, $226 \mathrm{Ga}$. 456, 459, 75 \$.E.2d $649,652(1970)$. The Supreme Court summarily reversed in light of Surann: "in this remedial process, steps will almost invariably require that students be assigned "differently because of their race." 402 U.S. at 41 . The Fourteenth Amendment provides no support for a restriction of federal busing orders cnacted alone.

But the restrictions on busing do not purport to be remedies for any denial of equal protection, and they were not enacted alone. They are only part of a comprehensive national effort to achieve equal educational opportunity that includes both traditional remedies for desegregation and the authorization for a new infusion of funds into poverty stricken schools; they aim only, as the President advised Congress, "to establish reasonable national standards." Message at 2. As a part of such a legislative plan, the busing restrictions can overcome the initial problems of legitimacy under the Fourteenth Amendment outlined above.

79. For some attempts to dig it out, see Oregon v. Mritchell, 400 U.S. 112, 142 (1970) (Harlan, J., dissenting); 1 C. Fairaian, Recossmuction aNd ReUNioN 1864.68 (1971), ch. 20; Bickel, The Original Understanding and the Desegregation Decision, 69 HAnv. L. REv. 1 (1955). Fairman suggests that the Amendment's real import never was clear:

Notwithstanding the pronouncement that it had been thoroughly understood by

the voters, we know that in truth it had not been understood even by its framers.

A form of words had been made supreme law.... [T] [Tat Congress would take

little part in the unfolding of the amendment-that the Court vould become the

agent for enforcing Section 1, ... are among the surprising observations about the

Fourteenth Amendment.

Supra at 1300 . Perhaps the only understanding that can safely be attributed to the framers of the Amendment is the understanding "that it was a constitution they were
writing." Bickel, supra at 13.

80. Slaughterhouse Cases, 77 U.S. (10 Wall.) 273 (1870).

81. 109 U.S. 3 (1883). See also United States v. Harris, 105 U.S. 629 (1882); United

States v. Cruikshank, 92 U.S. 542 (1875).

82. 77 U.S. (10 Wall.) 273 (1870).

83. 28 U.S.C. $\$ \$ 1971,1975(\mathrm{a})$-(d), 2000(a)-2000(h-6) (1970). See Heart of Atlanta Motcl v. United States, 379 U.S. 241 (1964); Katzenbach v. MicClung, 379 U.S. 294 (1964). 
strictive reading of Section 5 during the civil rights era-partially in South Carolina v. Katzenbach, ${ }^{84}$ and then completely in Katzenbach v. Morgan..$^{85}$

\section{A. Morgan and Section 5}

Congress edged toward a bold assertion of power under Section 5 of the Fourteenth Amendment when it turned to a similar source of constitutional authority in the Voting Rights Act of 1965.80 The Fifteenth Amendment declares in Section 1 that "the right of citizens of the United States to vote shall not be denied or abridged by the United States on account of race, color, or previous condition of servitude." Section 2 grants Congress enforcement power in language virtually identical to that of Section 5 of the Fourteenth Amendment. In South Carolina v. Katzenbach, the Court found that Congress, by virtue of Section 2, had "full remedial powers to effectuate the constitutional prohibition against racial discrimination in voting" 87 and specifically rejected the argument that "the task of fashioning specific remedies or of applying them to particular localities must necessarily be left entirely to the courts." "s8 Those portions of the Act before the Court, which permitted the Attorney General to suspend a state's use of a voter registration test or device and to call in federal registrars on finding that less than $50 \%$ of its voting age residents were registered to vote or voted in the 1964 election, fell within the scope of congressional power under the Fifteenth Amendment. Chief Justice Warren applied the same standard to congressional power under Section 2 of the Fifteenth Amendment that Marshall had applied to the Commerce Clause: "This power, like all others vested in Congress, is complete in itself, may be exercised to its utmost extent, and acknowledges no limitations, other than are prescribed in the Constitution." 80

The potential impact of the Court's proposition that the enforcement clause of the Fifteenth Amendment and the Necessary and Proper Clause mean the same thing (at least as against the reserved

84. 383 U.S. 301 (1966).

85. 384 U.S. 641 (1966).

86. Pub. L. No. $89-110,79$ Stat. 437.

87. 383 U.S. at 326.

88. 383 U.S. at 327 . The Court dealt at some length with the prior and unsatisfactory attempts to eliminate voting discrimination through case by case litigation and focused the discussion of the Voting Rights Act chiefly on its remedial provisions. II. at 323.37. The case, unlike Morgan, says nothing about congressional power to define discrimintutury practices; it only cites cases invalidating a number of them. Id. at 311-12.

89. 383 U.S. at 327 , quoting Gibbons v. Ogden, 22 U.S. (9 Wheat.) 1, 196. 
power of the states) became evident during the same term when the Court applied it to the enforcement clause of the Fourteenth Amendment in Katzenbach $v$. Morgan. Section 4(e) of the Voting Rights Act, not at issue in the South Carolina case, enfranchised Puerto Ricans in New York City by effectively overruling parts of the New York election laws. ${ }^{90}$ It provided that no state could deny the right to vote in any election to an individual solely because he was illiterate in English if he had completed the sixth grade in an American flag school where the language of instruction was other than English.

In upholding $\S 4(\mathrm{e})$ on two related grounds, ${ }^{01}$ the Court effectively overruled the interpretation of Section 5 announced in the Civil Rights Cases and greatly expanded the scope of congressional power under Section 5 of the Fourteenth Amendment. Morgan suggests not only that Congress has authority under Section 5 to define as well as remedy denials of equal protection but also that the courts should defer to congressional exercise of that authority. Congress "brought a specially informed legislative competence" to its "general appraisal of literacy requirements for voting." "It is enough that we be able to perceive a basis upon which the Congress might resolve the conflict as it did." 93

Morgan's language, nonetheless, is "shrouded in ambiguity." By confining its holding and interpolating qualifications of reasonableness into the deference doctrine, Morgan could be reconciled with earlier interpretations of Section 5. But the Court seems to invite a

90. Katzenbach v. Morgan, 383 U.S. 611, 645 n.3 (1960). The New York Constitution, art. II, $\$ 1$ (1938) made English literacy a prerequisite for voting. $\$ \$ 150$ and 168 of the New York election law implemented the provision by cinpowering the Board of Regents to give literacy tests and permitting new voters to submit, in the alternative, certain evidence of education. Persons educated in Puerto Rico could make the alternative showing if their education had been "predominantly in the English langtage." N.Y. Election Law $\$ \S 150,168$ (McKinney 1964).

91. In the first branch of its holding, the Court argued that entranchising a large segment of the New York Puerto Rican community "will be helpful in gaining nondiscriminatory treatment in public services for the entire Pucrto Rican community." 348 U.S. at 652. The Court in this branch of its argument refused independently to determine whether state laws suspended by $4(\mathrm{e})$ violated the cqual protection clause; nor did it require an express congressional finding to that effect.

The Court also suggested, in a second and less novel branch of the opinion, that section $f(e)$ was constitutional if it reflected Congress' conclusion that une New York English literacy requirement discriminated against the class of Pucrto Ricans defined by the Act. But still the Court refused to examine the merits of Congress' conclusion; it was willing to let the congressional judgment control. The Court need only" "perceive a basis" for the congressional judgment that New York's English language literacy test violated the Fourteenth Amendment. $1 d$. at 655-56.

92. Id. at $655-56$.

93. Id. at 653. For a general critique of the case, see Bickel, The roting Rights Cases, 1966 S. Cr. REv. 79; see also Cox, Constitutional Adjudication and the Promotion of Human Rights, 80 HARv. L. REv. 91 (1966).

94. Burt, Miranda and Title II: A Morganalic Marriage, 1969 S. CT. REv. 81, 83. 
bolder reading, and a court considering the Busing Acts in its reexamination of Swann must reckon with Morgan's bolder propositions, in particular the doctrine of judicial deference to legislative judgment.

\section{If Morgan Falls}

Morgan has its critics, ${ }^{95}$ and they may be gaining ground. In the eighteen-year-old vote case, ${ }^{06}$ Morgan's suggestion that Congress may define the content of equal protection virtually without judicial scrutiny could command only four votes, ${ }^{07}$ and the composition of the Court has changed since that 1970 decision. Some serious faults in Morgan's argument and some reservations about its consequences suggest that a Swann II case might decline to follow it.

The Court in Morgan rested its decision in part on the historical judgment that the Fourteenth Amendment's authors intended Congress to be its prime enforcer. Although evidence exists to support such a view, so does strong evidence to the contrary. ${ }^{08}$ At the time of the congressional debates on the Amendment, there "was every reason for the supporters of the Fourteenth Amendment to look confidently toward the judiciary." ${ }^{\circ}$ In fact, the Amendment's authors may have pressed for a constitutional amendment principally because they wished to give the Court a constitutional weapon with which to protect these fundamental rights from emasculation by future Congresses. ${ }^{100}$ As a matter of historical interpretation, the Morgan Court

95. See, e.g., Bickel, supra note 93; Burt, supra note 94.

96. Oregon v. Mitchell, 400 U.S. 112 (1970).

97. Justices Douglas, Brennan, Marshall, and White thought that Title III of the Voting Rights Act of 1970, 42 U.S.C. $\$ \$ 1973 \mathrm{bb}-1973 \mathrm{bb}-3$ (1970), extending the vote in federal and state elections to persons between eighteen and twenty-one years of age, was a valid exercise of congressional power under Section 5 of the Fourteenth Amend. ment. Justice Black joined them on separate grounds to uphold the Act with respect to federal elections, but he-with the other four members of the Court-thought Congress could not set the voting age in state elections.

98. The majority in Morgan collected and relied upon a number of atuthoritics suggesting an active role for Congress under Section 5. See Katzenbach v. Morgatl, 385 U.S. 641, 648 note 7 (1966). Professor Burt is highly critical both of these authorities and the Court's use of them; he reaches a very different conclusion. Burt, supra note 91 ,
at $84-100$.

99. Burt, supra note 94, at 95 .

100. Professor Burt reaches this conclusion:

[I]t is against future Congresses that the amendment must be protected. No one in these debates suggested that the amendment could not be trusted in the hallds of the judiciary. However soon this belief was to appear, it was not voiced then . . . . If the central role in protecting the amendment from future depredations is ncces. sarily vested in the courts, and if that role was derived from an explicitly statcd mistrust of future Congresses, where then does one find that the essence of the amendment was to enlarge the powers of Congress vis-a-vis the courts? Id. at 93 . 
may have read the intent of the framers of the Fourteenth Amendment in the wrong way.

But whatever the role of Congress in enforcing the Fourteenth Amendment was meant to be, the Court is on at least questionable footing if it holds that Section 5 suspends, for the purposes of Fourteenth Amendment legislation, the enduring principle of Marbury v. Madison.101 The Court, not the Congress, defines the limits of congressional power under the Constitution. Morgan does suggest that the Court will defer without further inquiry to a congressional judgment that a violation of equal protection has occurred or is likely to occur. But the framers of the Fourteenth Amendment intended no such deference and no such change in the basic relationship of the Court to Congress. ${ }^{102}$ Only a state denial of equal protection could trigger the exercise of congressional power under Section 5: "Congress' view that the pre-condition has been met should be persuasive, but it cannot be decisive." 103 To the extent that Morgan counsels "abdicating judicial review," 104 both its wisdom and its vitality are open to serious doubt.

In the absence of Morgan and its doctrine of deference to congressional Fourteenth Amendment judgments, the busing bills must be subjected to constitutional inquiry of the kind required by the Civil Rights Cases; ${ }^{105}$ the Court must make its own, independent judgment as to whether the congressional remedies will actually remedy in each particular case the denial of equal protection found by the Court. The busing bills may still claim legitimacy under the

101. 5 U.S. (l Cranch) 137 (1803).

102. See Bickel, supra note 93. Professor Bickel concludes his discussion of the history of the Fourteenth Amendment:

Nothing is clearer ... than that its framers rejected the option of an open-ended grant of power to meddle with conditions within the states so as to render them equal in accordance with its own notions. Rather the framers chose to write an amendment empowering Congress only to rectify inequalities put into effect by the states. Hence the power of Congress comes into play only when the precondition of a denial of equal protection of the laws by a state has been met. Congress' view that the precondition has been met should be persuasive, but it cannot be decisive. That is the history of the matter.

Id. at 97 .

103. Id. at 97.

104. Id. at 98 .

105. 109 U.S. 3 (1883). See pp. 1559-60. The Court set out the nature of congressional power under Section 5 in these terms:

The legislation which Congress is authorized to adopt in this behalf is not general legislation upon the rights of the citizen, but corrective legislation, Unat is, such as may be necessary and proper for counteracting such lavis as the states may adopt or enforce, and which, by the amendment, they are prohibited from making or enforcing, or such acts and proceedings as the states may commit or take, and which, by the amendment, they are prohibited from committing or taking. 109 U.S. at 13-14. 
Fourteenth Amendment. But without Morgan's doctrine of deference, the Court hearing Swann II cannot end its inquiry by noting that the bills mandate certain remedies and prohibit others.

\section{If Morgan Stands}

Whatever broader constitutional problems Morgan may raise, it would bind the Court deciding a second Swann case. With Morgan's doctrine of deference to congressional judgment, the busing bills stand on different and perhaps firmer constitutional footing, since a principled application of Morgan's general rule would suggest that the Court defer to this legislative judgment as well. Several commentators have suggested such a use for Morgan, ${ }^{100}$ and Justice Harlan foresaw it in his dissent, when he warned that "Congress should ... be able as well to exercise its Section 5 'discretion' by enacting statutes so as in effect to dilute equal protection and due process decisions of this Court." 107

Although Morgan's doctrine of judicial deference has strong implications for the busing bills, the Swann II court could distinguish it in a number of ways. The 1965 Voting Rights Act broke new ground, extending both the definition of equal protection and the remedies for its denial in an area the Court had not yet occupied. The busing bills, on the other hand, cover matters first taken up in Brown v. Board of Education ${ }^{108}$ and developed in a long line of cases culminating, for the time being, with Swann. ${ }^{100}$ What the Fourteenth Amendment requires in the schools is clear, at least in principle. "Separate educational facilities are inherently unequal."110 School boards are "charged with the affirmative duty to take whatever steps might be necessary to convert to a unitary system in which racial discrimination would be eliminated root and branch."111 To discharge that duty, "school authorities should make every effort to achieve the greatest possible degree of actual desegregation."112 The received wisdom of the desegregation cases does not make the busing bills perforce unconstitutional, but it does suggest that they are a

106. See, e.g., Burt, supra note 94, at 118-23; Cox, supra note 93.

107. 384 U.S. 659, 668. He was joined in dissent by Mr. Justice Stcwart.

108. 347 U.S. 483 (1954).

109. For a history of these cases, see Johnson, School Desegregation Problems in the South: An Historical Perspective, 54 MiNN. L. REv. 1157 (1970); Note, Schools, Busing. and Desegregation: The Post-Swann Era, 46 N.Y.U.L. REv. 1078 (1971).

110. Brown v. Bd. of Educ., 347 U.S. 483, 495 (1954).

111. Green v. County School Bd., 391 U.S. 430, 437-38 (1968).

112. Swann v. Charlotte-Mecklenburg, 402 U.S. 1, 26 (1971). 
very different phenomenon, historically and perhaps constitutionally, from Section 4(e) of the Voting Rights Act of 1965.

Section 4(e) of the Voting Rights Act in effect suspended the enforcement of a New York law, and the Swann II Court could distinguish -and at the same time confine-Morgan by holding that congressional power under the Fourteenth Amendment is restricted to suspending state laws. ${ }^{113}$ Certainly the sections of the 1965 Voting Rights Act considered in South Carolina v. Katzenbach did only that, and so did the act considered in Oregon $v$. Mitchell, where four members of the majority thought the Fourteenth Amendment gave Congress power to set the voting age at eighteen in both federal and state elections. ${ }^{114}$ At the very least, it is clear that these statutes were upheld because they dealt with state action. The busing bills do not operate upon state law or attempt to affect state action; they work exclusively on the federal level and limit only federal courts. ${ }^{115}$

These distinguishing features of Morgan, although they affect its value as direct precedent for the busing bills, do not destroy the broader impact of its central doctrine. The Court should, in enforcing equal protection guarantees, defer to the legislature's judgment. Responding to Justice Harlan's suggestion that the deference doctrine cut both ways, the majority attempted to limit Morgan in the now famous footnote 10 :

Section 5 does not grant Congress power to exercise discretion in the other direction and to enact "statutes so as in effect to dilute equal protection and due process decisions of this Court." We emphasize that Congress' power under Section $\mathbf{5}$ is limited to adopting measures to enforce the guarantees of the Amendment; Section 5 grants Congress no power to restrict, abrogate, or dilute these guarantees. Thus, for example, an enactment authorizing the States to establish racially segregated systems of education would not be-as required by Section 5-a measure "to enforce" the Equal Protection clause since that clause of its own force prohibits such state laws. ${ }^{110}$

In effect, Justice Brennan argued that Congress may, under Section 5 of the Fourteenth Amendment, strike at state action that the

113. The Court's opinion is susceptible of a much broader interpretation. Professor Cox argues that Morgan provides Congress with the authority to regulate the franchise, to eliminate de facto segregation, and to adopt-under the Due process Clause of the Fourteenth Amendment-a comprehensive code of criminal procedure for the states. Supra note 97 , at 107.08 .

114. 400 U.S. 112 (1970). See note 97 supra.

115. See note 53 supra.

116. 384 U.S. at 652 n.10. 
Court could not reach, but it could not legitimate state action that otherwise violates the Fourteenth Amendment.

Reading Morgan with footnote 10 presents its own problems, most of which arise from the difficulty-or impossibility-of deciding whether a statute is a "restriction" or an "extension" of the Fourteenth Amendment guarantees. In new fields of Fourteenth Amendment law, the difficulty may be insurmountable. In Morgan, for example, Section 4(e) "extends" the right of non-English speaking Puerto Ricans to vote, but it arguably "restricts" the rights of English-speaking voter's not to have their votes diluted. Relaxing the footnote's limitation of Morgan would remove this problem, and it would permit the Court to give congressional judgments equal and conclusive weight whether the Congress sought to expand or narrow the current scope of equal protection. ${ }^{117}$

But the majority's footnote may not mean that the Court will consider legislation it likes an "expansion" and legislation it dislikes a "restriction" of Fourteenth Amendment guarantees. It may mean simply that the Court reserves the right to make a full-scale Marbury review of Section 5 legislation that threatens well-established Fourteenth Amendment doctrine, upholding the statute only if it is consistent in the particular case with the court's view of the Constitution's requirements. Certainly the Court's use of school desegregation as an example in footnote $10^{118}$ suggests such an interpretation. In any event, the footnote stands, and the court reconsidering Swann in light of the busing bills must decide, under Morgan, whether the bills extend or restrict established Fourteenth Amendment rights. ${ }^{110}$

The Court could avoid such a judgment, of course, by relaxing the footnote's limitations, and two basic arguments suggest that Morgan's deference rule should extend to cover restrictions of Fourteenth Amendment guarantees. First, it may be contended, Congress is a more competent institution than the Court for making certain kinds of decisions about equal protection, and the Court therefore should

117. See Burt, supra note 94, at 115-18, for a more eloquent exposition of this argu. ment. See also Cox, supra note 93, at 106 n.86. Professor Cox, in an article cvidently written before Swann, makes a similar argument in suggesting that Congress act to solve the constitutional problems of remedying school desegregation by using its Section 5 authority. Cox, The Role of Congress in Constitutional Determinations, $10 \mathrm{U}$. CiN. cinNati L. Rev. 199, 257-61 (1971).

118. See p. 1565.

119. "[With footnote 10], the Morgan opinion appears a tour de force. To rcgulatc activities that the Court wishes to reach under the Fourteenth Amendment, but cannot itself justify regulating, the Court has enlisted congressional assistance. But the Court will set the basic terms. Congress can only fill in the blanks." Burt, stupra note 91, at 118. 
defer in all cases to the congressional judgment. Second, it may be argued, the authors of the Fourteenth Amendment intended Congress to play a major role in enforcing it, and the Court ought to defer consistently to Congress for that reason. Should the Swann II Court apply these arguments to the area of school desegregation and disregard footnote 10 in considering the busing bills?

The first argument, going to institutional competence, draws support from two parts of Morgan. Justice Brennan noted that Congress brought "a special competence" to the Voting Rights Act because of each member's necessary familiarity with the process of getting elected.120 $\mathrm{He}$ suggested too that Congress brought a "general competence," greater than a court's, to a range of Fourteenth Amendment cases beyond those concerning voting rights because of its capacity for sophisticated and detailed judgments. Congress, Justice Brennan's argument suggests, can compromise conflicting principles in a way that courts cannot, and it can calibrate both the scope and the nature of its enforcement much more finely than a court. ${ }^{221}$

In the area of school desegregation, however, neither the "special" nor the "general" congressional competence are strong enough to compel deference. Congress has no "special" competence in the schools area of the kind it has in the voting area. ${ }^{122}$ Whatever advantages it has over a Court in developing school desegregation policy are a function of the advantages of the legislative process and not a result of any close contact with schools. The usual rules of statutory construction take into account such inherent advantages, and no special rule is needed to reflect them.

As to "general deference," Justice Brennan's reasoning in Morgan

120. 384 U.S. at 656 .

121. Professor Burt suggests this "different, much firmer rationale" for Morgan: [C]learly Congress is less burdened by the principled constraints under which courts labor. Congress, using no principle but fiat by majority votc, could act, for example, to permit Mrs. Murphy to turn away black lodgers so long as she lived with her other lodgers in a house that could accommodate no more than four families. Congress could easily conclude that in MIrs. Mrurphy's case, but not in others closely analogous, the values involved in free choice of companions should predominatc. The Court would have much greater difficulty independently constructing an cxemption for Mrs. Murphy, no matter how important some such exemption might be, in order to mediate the clashing principles and political pressures at stake. The Mrs. Murphys of the country are more likely to find spokesmen in the legislature than in the courts, and the Murphy voices or silences can be noted by the legislature, which then is able to make a reliable decision about where it might be politic to temper the application of proscription against private diserimination. In this context -devising appropriate adjustment of directly conflicting principles-the legislative mechanism is greatly superior to the courts.

Supra note 94 , at 110,112 .

122. If any branch of government has become familiar with the problems of school desegregation, in the way that congressmen become familiar with the clectoral process,
it is the federal courts. 
and other cases ${ }^{123}$ implies that the Court need not and should not defer to Congress in areas where both the Court and Congress can make the judgments necessary to enforce the Fourteenth Amendment. Courts should defer not because Congress is more competent than the courts but because Congress is competent to make certain kinds of judgments requiring detailed factual inquiries, and courts are not. ${ }^{124}$ Seventeen years of experience with desegregation decisions support the proposition that this area is within judicial competence.

In passing the busing bills, ${ }^{125}$ Congress would be balancing some of the same factors that the Swann court instructed trial judges to assess in fashioning a busing order, including the age of the children involved, the distance travelled and the time spent on the bus, the nature of the area and the hazards of the trip. ${ }^{126}$ It might be argued that the Court should acknowledge the congressional superiority at the traditionally legislative task of "balancing" and defer to Congress' judgment. But the Court in Swann spoke of a very different kind of balancing than that achieved by the flat, nationwide formulae of the busing bills: a case by case determination, based on local conditions and local data. ${ }^{127}$ For this kind of balancing, the courts, not Congress, would seem to be the more competent institution.

So the Court considering Swann II need not relax the limits placed by footnote 10 on Morgan because Congress is more competent in school desegregation. Nor does the history of Section 5 require such a relaxation. Where, as in the busing bills, Congress seeks to limit current remedies for state denial of equal protection, the history of the Amendment would seem to call for close scrutiny rather than automatic deference. ${ }^{128}$

\section{B. Morgan and Congressional Power}

Whether Morgan stands or falls, then, the busing bills would face a serious constitutional test in Swann II. Without Morgan, the Court

123. Oregon v. Mitchell, 400 U.S. 112 (1970).

124. Id. at 248 .

125. See note 13 supra.

126. 402 U.S. at 29-31. The Court indicated that the task of balancing, although complex, was within a court's competence: "The reconciliation of competing values in a desegregation case is, of course, a difficult task with many sensitive facets but fundamentally no more so than remedial measures courts of equity have traditionally cmployed." Id. at 31 .

127. "In this area [remedial alteration of attendance zones], we must rely to a large extent, as this Court has for more than sixteen years, on the informcd judgment of the district courts in the first instance and on courts of appeals."

"Conditions in different localities will vary so widely that no rigid rules can be latil down to govern all situations." Swann v. Charlotte-Mecklenburg, 402 U.S. 1, 28.29 (1971).

128. See pp. 1559.60, 1562-63. 
must decide whether effective desegregation could be achieved within the bill's limitations; if it could not, then the court would simply have to ignore the bill pursuant to Marbury v. Madison. ${ }^{120}$ And with Morgan, the court-because of the majority's footnote-faces much the same question: Do the busing bills "extend" or "restrict" the rights guaranteed by the Fourteenth Amendment?

But the Supreme Court in Swann v. Charlotle-Mecklenburg effectively determined how the Court in a hypothetical Su'ann II would characterize the remedy limited by the busing bills under either regime. Busing, one remedy among many, becomes a right when it is the only way in which a district court can achieve the "greatest possible degree of actual desegregation."130 With or without Morgan to support them, the busing bills go too far in restricting a child's right to attend schools in a desegregated district.

District courts have used or considered a number of methods in desegregating the public schools. Courts have redrawn school attendance zones to make them more compact and more balanced; they have gerrymandered zones, making them less compact but more balanced; they have paired a substantially white school with a substantially black school, ordering half of the grades held at one school and the rest at the other school. Courts have also approved desegregation plans that call for closing older schools in racially impacted neighborhoods and building new schools in areas accessible to both races. Some school boards have implemented plans that call for the construction of central, magnet schools and "educational parks."132 Swann mentions most of these methods, ${ }^{132}$ and the Equal Educational Opportunities Bill incorporates them into its schedule of remedies. ${ }^{133}$

But the Bill obscures what Swann expressly recognizes. Each of these methods of desegregation may, depending upon the racial demography of the school district involved, require that students be bused to their new schools.134 In Swann, the Court dealt with a school district of 60,000 white students and 24,000 black students; 14,000 of the blacks attended schools that were $99 \%$ black. In order to spread the black students, most of whom lived in the central city,

129. 5 U.S. (1 Cranch) 137 (1803).

130. 402 U.S. at 26.

131. For a full discussion of these remedies and cases of each. sce Note, Sehools, Busing and Desegregation: The Post-Swann Era, 46 N.Y.U.L. REv. 1078 (1971); Comment, Busing, Swann v. Charlotte-Nfecklenburg, and the Future of Desegregation in the Fifth Circuit, 49 Tex. L. REv. 884 (1971).

132. 402 U.S. at $22-31$.

133. \$ 402; see note 11 supra.

134. 402 U.S. 1 at 29-31. 
over a district of 550 square miles the district court gerrymandered school attendance zones, created "satellite zones"135 and paired inner-city schools with one or more white schools. The district court had specifically rejected an alternative plan that used only gerry. mandering to desegregate elementary schools. Instead, it grouped nine inner-city schools with twenty-four suburban schools. ${ }^{130}$ The district court's plan, no matter what name is given to the techniques it used, required more busing-the school district would have to purchase 138 more buses, the court found, to implement the plan. ${ }^{137}$

Under Swann's standard, in large school districts like CharlotteMecklenburg the alternatives are simple: transport students or continue to have a substantial number of racially identifiable schools. The busing bills' insistence that there are "other remedies" cannot alter that fact. Busing and desegregation are questions of degree; even Swann set as its goal a "degree" of desegregation. Nor, as Swann recognized, is desegregation synonymous with racial balance. But precisely because desegregation is a question of degree, a point comes when the failure to move further toward racial balance becomes a failure to desegregate. And if moving further means more busing, then the Equal Protection Clause requires, as it did in Swann, more busing. ${ }^{133}$

The Swann Court expressly considered and approved of the district court's finding that "assignment of children to the school nearest their home serving their grade would not produce an effective

135. In "satellite zoning," students from a central city zone attend school with students from an outlying zone.

136. These data are taken from the Court's discussion, 402 U.S. at 6.11.

137. Id. at 30 , n.12.

138. Professor Bork, although he strongly defends most of the busing bills, is willing to say only that a "good case" can be made for the constitutionality of the restrictions on busing elementary school children. Bork, supra note 15, at 21.22. This featture $\$ 409$ (a) of the Equal Educational Opportunities Bill-is of course the crux of the busing plant. Professor Bork devotes a bit more than a page to its defense, and he hinges his argll ment on the assertion that there "are many remedies other than busing available to courts ...." Id. at 22. He might argue in the same vein that Swann was not a "con. stitutional decision," since it dealt with remedies and not rights. Becaluse busing is onc remedy among many, Bork argues, the Equal Educational Opportunities Bill leaves intact the duty Brown imposed upon formerly segregated school districts. Such an argumcut creates an artificial distinction between rights and remedies; the right which cannot be vindicated is not a right at all, and the most that can be said for the distinction is that it may be useful where a right can be vindicated in several ways. Professor llork's right-remedy distinction simply assumes the answer to the central question. If bushy is in some cases-as it was in Swann-the only remedy that would produce desegregation in any real sense, then Professor Bork's argument falls. The real question about the constitutionality of the busing bills is the question that Bork hesitates to answer di. rectly: to what extent does the Equal Protection Clause require that once segregated schools achieve a racial balance? Swann, of course, had a simple and dircet answer: to the greatest extent possible. 
dismantling of the dual system ...."130 In a companion case to Swann, North Carolina Board of Education v. Swann, ${ }^{1+0}$ the Court struck down a North Carolina anti-busing statute, citing the principal Swann case and explaining that "bus transportation has long been an integral part of all public educational systems, and it is unlikely that a truly effective remedy could be devised without continued reliance on it."141 A retreat from Swann's strong rule, before the busing bills or some other indication of congressional displeasure, is always possible. Congress, as a coequal branch, has a role to play in the process of constitutional adjudication, and its opinions should command the Court's serious consideration. ${ }^{142}$ But under Swann, busing is one truly effective remedy-and in Swann the only such remedy-for the denial of equal'protection in the schools.

Section 5 of the Fourteenth Amendment, then, structures but does not determine the outcome of the court's inquiry into the busing bills in Swann II. Reading Section 5 without Morgan, the Court should uphold the bills only if, in the district before the court, the substantive mandate of the Amendment can be carried out within the limits set by the bills. Swann and its companions suggest that there will be some districts-including Charlotte-Mecklenburg-where it cannot. If the Court applies Morgan's reading of Section 5, the bills are on stronger ground because of the doctrine of judicial deference to congressional judgment in the enforcement of the Fourteenth Amendment. But the Morgan Court, whatever it yielded of the territory gained in Marbury v. Madison, reserved a question that the Swann II Court must answer before it may even apply the deference doctrine: Does the measure constitute an extension or a restriction of Fourteenth Amendment guarantees? Swann and its companions suggest that the busing bills restrict the rights of children in some districts to attend desegregated schools.

139. 402 U.S. 1 at 30 .

140. 402 U.S. 42 (1971).

141. Id. at 46. The statute, N.C. Gev. STAт. \$ 115-176.1 (Supp. 1971) read in part: No student shall be assigned or compelled to attend any school on account of race, creed, color or national origin, or for the purpose of creating a balance or ratio of race, religion or national origins. Involuntary busing of students in contravention of this article is prohibited, and public funds shall not be used for any such busing.

142. "The Court may defer to the judgment of a co-equal branch of government even when it believes that it need not. Or the justices may be persuaded 10 a different view of a subject by the informed opinion of the legislature. At the rery least, a de. liberate judgment by Congress on constitutional matters is a powerful brief laid before the Court. A constitutional role of even such limited dimensions is not to be despised. It has the virtue of persuading Congress to play a fuller and more active role in constitutional questions without the inhibiting thought that every such occasion must provoke a confrontation between two great branches of government." Bork, supra note 15 , at 5-6. 
To the extent this is so in such districts, the bills are beyond Congress' power under Section 5. Whether Morgan stands or falls, the Court in Swann II must make the crucial constitutional judgments about the busing bills in terms of the desegregation decisions and the Equal Protection Clause of the Fourteenth Amendment, not in terms of Section 5.

\section{Conclusion}

A court trying to reconcile Swann's interpretation of the Fourteenth Amendment with the Busing Acts will find no easy escape from facing again and deciding again Brown's unresolved question: To what lengths must a once segregated school district go in order to eliminate racial segregation "root and branch?" Article III of the Constitution gives Congress power to create inferior courts and regulate the appellate jurisdiction of the Supreme Court but leaves with the Court the ultimate responsibility for deciding what the Fourteenth Amendment requires. The most sweeping assertions of congressional power under Article III have been accepted by the Court only because they could be cast as congressional choices of remedy. Congress may choose among remedies by regulating jurisdiction as it wishes, but "jurisdiction always is jurisdiction only to decide constitutionally." 143 Whatever power over remedies Article III gives Congress, it is a power to grant or withhold particular remedies, not constitutional rights.

Section 5 of the Fourteenth Amendment, with or without Morgan's doctrine of judicial deference to congressional judgment, grants Congress no greater power than Article III. Congress under Section 5 may mandate certain remedies and combinations of remedies, but the Court deciding Swann II must still decide, in Hart's phrase, "con* stitutionally." It must determine whether the denial of equal protection can be remedied within the limits of the congressional plan. Without Morgan, the question may be cast differently, but it will be answered the same way. As Chief Justice Burger wrote recently, "Congress does not have the power to authorize the individual states to violate the Equal Protection Clause."144 Congress may enact remedies; it cannot, even under Morgan, abrogate rights.

Swann suggests that busing has become a right in large and demographically complex school districts because the last vestiges of segrega-

143. Hart, supra note 59, at 1402.

144. Graham v. Richardson, 403 U.S. 365,382 (1971). 
tion can be removed in no other way. But the busing remedy remains a constitutional right-even in such districts-only as long as the Court adheres to the principle that "separate educational facilities are inherently unequal."145 The Nixon busing bills, like any bill restricting a court's power to order busing, challenge that principle. The Court may think Brown's central proposition wrong, or at least too simplistic in an age of growing sophistication about education. But the Court, if so inclined, must make that judgment explicit, for the busing bills affect rights, not remedies, and they challenge both Brown and Swann.

145. Brown v. Bd. of Educ., 347 U.S. 483, 495 (1954) (emphasis added). 